\title{
The Patarei Sea Fort: Perspectives on Heritage, Memory and Identity Politics in Post-Soviet Estonia
}

\author{
Onessa Novak \\ Personal Assistant of Prof. R. Braidotti at Utrecht University, Utrecht, The \\ Netherlands \\ onessa.novak@gmail.com \\ Gertjan Plets \\ Assistant Professor in Cultural Heritage and Archaeology, Department of \\ History and Art History, Utrecht University, Utrecht, The Netherlands \\ g.f.j.plets@uu.nl
}

\begin{abstract}
This paper studies the struggle over the rehabilitation of the Patarei Sea Fort in Tallinn (Estonia), a former prison where during the Soviet period political prisoners were held and corralled before deportation to Siberia. We explore how three groups of stakeholders assemble and define the future of the site: The Estonian State; NGo Eesti Muinsuskaiste Selts (the Estonian Heritage Society); and Europa Nostra. Each of these groups have a competing future for the site in mind. The struggle over the Patarei Sea fort is connected to discussions over heritage politics in those countries that entered the European Union around the early 200os. In comparison to other memory practices in the region, the Patarei Sea Fort is not instrumentalized by the state to support a national historical narrative othering the Russian Federation. Rather the state's engagement with the site is restricted and textured by ambitions to gentrify the district it is situated in. Not the state, but an NGO, assisted by a European heritage association, promotes a heritage discourse geared at strengthening the Estonian national narrative.
\end{abstract}

\section{Keywords}

post-soviet heritage - Estonia - politics of history and memory - gentrification national narratives 


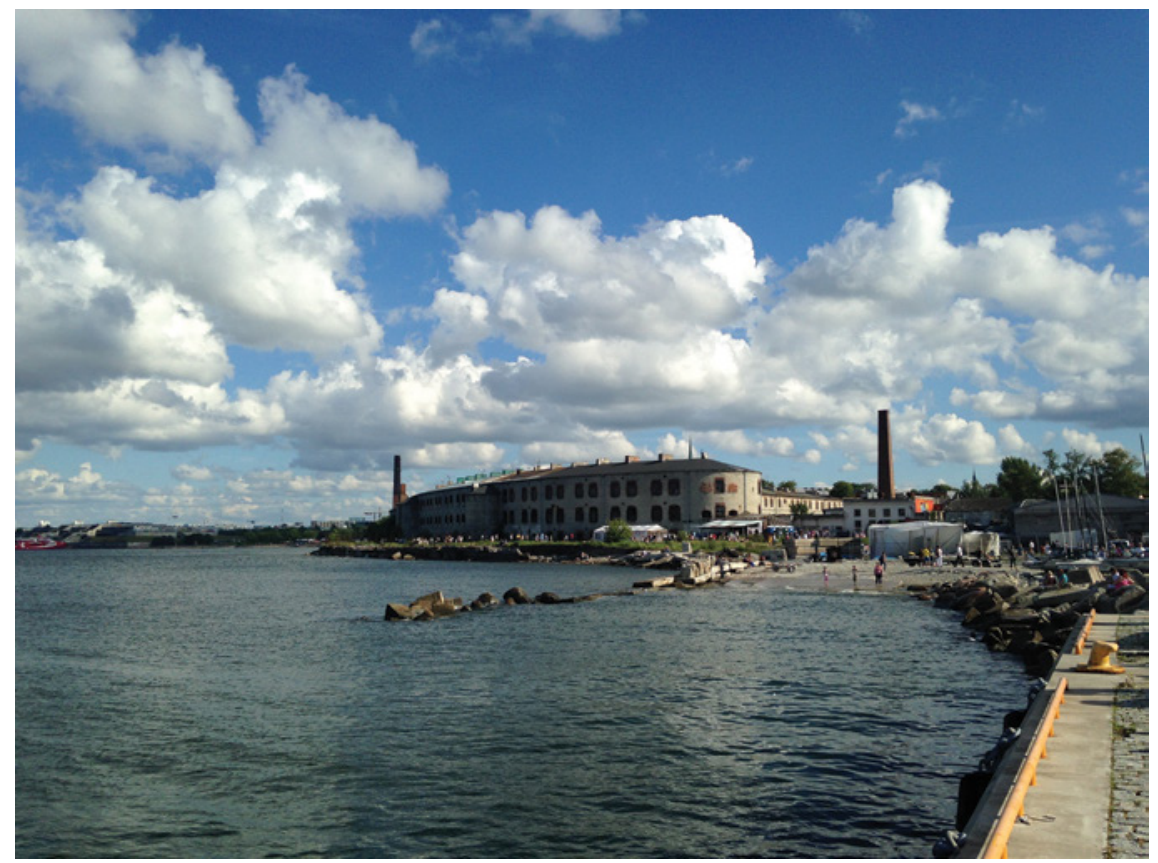

FIgURE 1 The Patarei Sea Fort in summer 2016

PHOTOGRAPH BY GERTJAN PLETS FROM PERSONAL COLLECTION

On the night of 31 April 2017, a part of the roof of the Patarei Sea Fort (Fig. 1) in Tallinn blew off during a severe storm, inflicting great damage upon the protected heritage site. ${ }^{1}$ That this happened was not a big surprise. The building had not been maintained for over fifteen years. From 1918 until 2002 the fort had been in use as the central prison of the city of Tallinn in Estonia. During the Soviet and Nazi occupations political prisoners were imprisoned, tortured and executed in Patarei, casting a dark shadow over the site. In 2002 the central prison moved to a new building because the state could not afford the high maintenance costs of the building. After the building lost its purpose, it was neglected, and the conditions worsened over time. ${ }^{2}$

1 "Patarei Sea Fort in Tallinn Severely Damaged in a Storm," http://www.europanostra.org/patarei-sea-fort-damaged-storm/ (accessed on 25 July 2017).

27 Most Endangered, 7 Most Endangered 2016: Patarei Sea Fort - Report (Luxembourg, 2016), http://www.europanostra.org/wp-content/uploads/2017/o1/7ME-2016-Estonia-Patarei-Report.pdf, 1-22, at 2. 
As the neighbourhood in which the site is located began gentrifying rapidly, the prison became valuable real estate. Because the restoration of the site would also come at an immense cost (approximately 110 million Euros), the owner of the fort, the Estonian state, decided to sell it to a private investor. In 2004 the state appointed the state-owned real estate company Riigi Kinnisvara AS (RKAS) to sell the building and transfer it into private hands. ${ }^{3}$ Over time, auction and redevelopment plans became more concrete and the site was under threat of becoming private property. This decision was met by opposition from the Eesti Muinsuskaitse Selts (the Estonian Heritage Society, EMS) and Europa Nostra, who considered the fort to be of historical and national significance. According to EMS and Europa Nostra, the Patarei Sea Fort is an embodiment of the tumultuous national past of Estonia; especially its connection to histories of Soviet occupation and atrocity should not be forgotten.

Multiple histories are encoded into the material fabric of the dilapidating fort. It was commissioned in the 1820 s by the Russian Tsar Nicolas I as a fortification to protect the Russian Empire from dangers coming from the Baltic Sea. Construction was completed in 1840 . During the Crimean War (1853-1856) Patarei was used as a fortification and after that, due to changes in warfare tactics, it lost its defensive function. From 1918 onwards, Patarei became the central prison of Estonia and fulfilled that purpose until 2002. ${ }^{4}$ The most contested chapter of Patarei's complex cultural biography is without a doubt its role in the Soviet period. During the first and second Soviet occupation (1940-1941 and 1944-1991) the prison held political dissidents and prisoners of war, alongside regular criminals. People were held in the prison awaiting their trial or deportation to Siberia. During the Nazi occupation (1941-1944), the prison functioned as a transit concentration camp, and it also held prisoners of war and political dissidents. Some executions also took place in the prison both during the Nazi and Soviet period. The last execution was in 1992, which was one year after the declaration of independence. ${ }^{5}$

Preservation initiatives have been limited since the 1990s, and especially since it was decommissioned as a prison. Although the Estonian state limited its investments in the site, the EMS was allowed to organize tours in the prison. Over the years these tours became increasingly popular amongst tourists interested in dark tourism and urban exploring. Slowly, inhabitants of Tallinn also started attending the tours and gradually the former prison became a frequently

37 Most Endangered, 7 Most Endangered 2016, http://www.europanostra.org/wp-content/ uploads/2017/01/7ME-2016-Estonia-Patarei-Report.pdf, 1-22, at 2.

4 Belford 2013, 50.

5 Belford 2013, 50. 
visited historical site for the locals. It even started as a central place of interest during the harbour days in the summer of 2016, attracting thousands of visitors in a couple of days. Frustrated with the plans of the government to sell the site, and taking into account its popularity and its 'national' significance, the EMS in 2016 nominated the Sea Fort for Europa Nostra's ' 7 Most Endangered' programme, hoping that international attention would make the government realize that the past the fort represents is important for the Estonian national identity. Later in 2016, the site ended up on the $7 \mathrm{ME}$ list because of its historical and architectural significance. However, despite the growing popularity, in October 2016 RKAs decided that the site was in such bad shape that it was a danger to the visitors and therefore closed it to the public. ${ }^{6}$ Ultimately in 2019 the fort was reopened after the 2016 closure. Part of the prison was turned into an exhibition about Soviet atrocities and imprisonment. In an atmosphere of the growing vilification of Estonia's neighbour Russia, the exhibition 'communism is prison' has already attracted more than 36,000 visitors.

In this paper we will investigate the different heritage discourses employed by different players vis-à-vis this prison. We will approach them as cultural texts, meaning that they can be hermeneutically read and deconstructed, yielding insights about the sociocultural contexts in which heritage becomes assembled in Estonia. At the same time by deconstructing the process of the divergent heritagization of Patarei, we gain insights into the political agendas of their producers. ${ }^{7}$ Three key stakeholders that approach the site in different but competing ways will be explored: (1) the EMS, a cultural NGO actively advocating for the preservation of Estonian national heritage, believing that the building must stay in the hands of the government and that the dark communist past encoded in the site should be addressed more explicitly. (2) The Estonian government that despite the valuable political and cultural symbolism encoded in the prison has largely neglected the site and decided to sell it to a private investor. (3) Europa Nostra, a cultural NGO connected to the European Union (EU), actively promoting European culture and identity, supports the Estonian NGO and has labelled the site one of Europe's most significant heritage sites which is under threat.

This paper draws on ethnographic and archival data collected during multiple visits to Tallinn in 2014, 2016, and 2017. During this period both authors travelled multiple times to Estonia to interview the main protagonists defining the memory culture of the prison. Interlocutors were asked about their perceptions of the former prison, using open-ended interviews in which there was

6 "Patarei Sea Fort in Tallinn Severely Damaged in a Storm".

7 Erll, 2011. 
attention to both specific heritage discourses and their perception of the sociopolitical context in which they operate. Policy texts, legal frameworks, and representations in the popular media about the prison were also collected to understand earlier mobilizations about Patarei. Finally, the main author was allowed to conduct participant observation with the EMA in October 2017 and follow their day-to-day activities. As all primary data was collected on site in 2016 and 2017, this paper will predominantly interpret heritage mobilizations during the period 1990-2017. At the end of the paper the recent developments will be presented, using an analysis of online sources and digital newspaper articles. It is important to note that due to the ongoing conflict between Estonian and Russian groups, it was impossible to systematically collect information on how the Russian minority perceives the site. The authors got the impression that representatives of this group were hesitant or reticent to answer the authors' questions, perhaps regarding the authors with some suspicion.

This article consists of six parts. First we provide important historical background on Estonia connected to the Patarei Sea Fort. We pay specific attention to the post-Socialist transformations that have shaped Estonia's socioeconomic fabric and the changing role of the prison within it. In the part 'In Search of a National History' we explore and interpret the heritage discourses of the main protagonists and how they interpret and mobilize the site in relation to their political agendas. Here we discuss their actions and connect them to the sociocultural fields of practice in which they are embedded. Third, we study the systematic neglect by the Estonian state during much of the 1990s and early 2000 s and connect it to Estonian nation-building following the collapse of the Soviet Union, which largely ignored the Soviet past. In the fourth part we examine the activism of the EMS and the explicit stance it takes vis-à-vis the Soviet past. The narrative positioning the Estonian ethnic group as noble victims of Soviet authoritarianism will be further explored. We then look at how EMS skilfully used the Europa Nostra label to strategically further their agenda and acquire external legitimacy for their heritage discourse. Europa Nostra is itself an independent player geared at producing a European heritage discourse. Finally, in the sixth part we analyze the engagement of the Estonian state and municipal government of Tallinn with the site since mid-2005. Following the integration in the European Union, the state promoted a more activist, anti-Soviet narrative, employing sites and memorials related to the socialist period as nation-building tools to normalize a non-Russian European image of the nation. Patarei would prove itself as an appropriate site of heritage politicking. However, we contend that the site was not mobilized because of neoliberal agendas. This clearly shows that heritage politics is not primarily defined by identity politics. 
Estonia has a complex past defined by successive occupations. The country was occupied by either Nazi Germany or the Soviet Union from 1940 until 1991. Before that the country had known merely twenty-two years of independence, making the independence acquired in 1991 and lasting until the present the longest lasting period of uninterrupted independence the country has ever known. After the dissolution of the Soviet Union, historical inquiries mainly focused on uncovering a national history countering Soviet understandings of the Estonian past. These inquiries were focused on deeply rooting the nation in ancient times, which could operate as a vehicle for national healing between the different ethnic groups defining Estonian society. Consequently, during most of the 1990s the Soviet era was largely reified by the state as a rupture which should be ignored, and all historical focus should be turned towards the

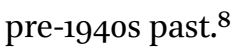

When thinking about Estonia in a post-Socialist perspective, it is important to realize that Estonia and the other Baltic States were part of the Soviet territory itself since 1940, instead of a satellite state like other countries on the eastern side of the Iron Curtain. ${ }^{9}$ In order to enforce the Russification of the Baltic States, and to make the integration into the Soviet Union easier, a great number of Russians were sent to the Baltic States after the 1940s. Nowadays, in Estonia the Russian speaking minority makes up about 25 per cent of the total population of 1.4 million citizens. In the capital city Tallinn about 37 per cent of the population is Russian, and in Narva (a city at the border of Russia) the Russian speakers make up 94 per cent of the population. ${ }^{10}$ These demographics only take into account those Russians who have Estonian citizenship; there are probably even more Russians living across Estonia.

The majority of the Russian speaking minority descends from industrial workers that were sent to Estonia after 1940 to accelerate the Russification. After the independence of 1991, all Russians that lived in Estonia before 1940 were naturalized. However, the ones that came afterwards were perceived as migrants and therefore could only acquire the nationality by taking an Estonian language and constitution test and they had to officially pledge their loyalty to the Estonian state. ${ }^{11}$ It is important to note that during the occupation, Russian

\footnotetext{
$8 \quad$ Kõresaar and Jõesalu, 2016, 131.

9 Kavaliauskas 2011, 320-321.

10 Amnesty International, "Estonia: Linguistic Minorities in Estonia: Discrimination Must End" (2006), https://www.amnesty.org/en/documents/EUR51/oo2/2006/en/

11 Amnesty International, "Estonia," https://www.amnesty.org/en/countries/europe-andcentral-asia/estonia/
} 
was the official language spoken in Estonia. Only after regaining independence, Estonian became the official language again and therefore the Russianspeaking minority did not need to speak Estonian until after Estonia regained its independence. ${ }^{12}$ Amnesty International and the United Nations pressured Estonia to stop the discrimination against the Russian population in 2006, and asked the country to make acquiring the Estonian nationality easier for this minority. Changes were made at that time, but the socioeconomic inequality between the groups nowadays is still striking. The socioeconomic situation of the Russian-speaking population is problematic, and only half of this minority has been successfully integrated in cultural and political respect. ${ }^{13}$

Although a significant part of the Estonian population consists of the Russian-speaking minority, after the country regained its independence most activities concerned with history were geared towards uncovering a national mono-ethnic past. History books were rewritten and alterations were made to the urban landscape of Tallinn. Soviet monuments, street names, and heritage sites were erased from the urban landscape as a form of 'decolonization'. Despite changing historical imaginaries, the vast Russian minority living in Estonia stayed in place. By erasing the remains of the Soviet occupation, the representation of this group in the urban areas also slowly disappeared, creating frictions with the dominant Estonian ethnic group. For instance, the removal of the Bronze Soldier, a Soviet wwII monument that used to be located in the centre of Tallinn, led to riots in 2007. ${ }^{14}$ Also, the Vabamu museum of Freedom and Occupations located in the centre of Tallinn (formerly known as Museum of Occupations until 2018) was vandalized during those riots. This museum often attracts negative reactions because the name implies that the Russians, and therefore also the Russian speaking minority, is the main perpetrator in the Estonian past while the country has been the subject of many other occupying forces.

The reactions to the neglect of Patarei are not as extreme, but nonetheless the fear of losing a heritage site that represents this complex past does evoke reactions from certain groups in Estonian society. Although the Russianspeaking minority does not voice its opinion as strongly about this heritage site, as it conveys a different message than that of the Bronze Solider, EMS and the government are quite vocal about their opinions concerning the fate of the heritage site. The Estonian Heritage Society believes that the difficult past

12 Tammaru et al. 2013, 846.

13 Katja Koort, "The Russians in Estonia: Twenty Years After," http://www.worldaffarisjour nal.org/article/russians-estonia-twenty-years-after (accessed on 25 July 2017).

14 "Tallinn Erupts into deadly Riot," The Baltic Times, April 28, 2007. https://www.baltictimes .com/news/articles/17774/. 
connected to the fort should be remembered. Selling the site would mean that the government evades the risk of angering the Russian speaking minority, but also that it will earn money because it is located in a gentrified area, mainly inhabited by the Russian-speaking minority. Supporting the gentrification of the area would likely push the minority out of their neighbourhood.

However, although the government is trying to stay 'neutral' about the past of Patarei, after the central prison moved out of the building in 2002, the state, and later RKAS, gave permission to a member of EMS to give guided tours and manage cultural events in the building so the site would stay in use until a new purpose was found. This was a strategic decision as buildings deteriorate less quickly when in use. At first, it was hard to attract visitors due to the dark past of the building, since the prison was also used during both the Nazi and the Soviet periods as the main detention centre for the imprisonment of political dissidents. Following broader trends in global tourism, over the years these 'dark heritage' tours became increasingly popular among tourists. ${ }^{15}$ Inhabitants of Tallinn started attending the tours and the former prison gradually became a frequently visited historical site for the locals. EMS believes that preserving the heritage site is of great national and historical importance and that it is a bad decision to close the fort for the public and to sell it to a private investor. If it were sold, it would be difficult to control the narrative in which such a problematic past is told. It is also uncertain whether the past would be communicated at all once it falls into private hands.

\section{In Search of a National History}

The politics of history are as much about actively remembering and transforming the materiality of the past into meaningful heritage sites, as they are about allowing sites to slowly turn into ruins. Neglecting a building, just as restoring or using it as a commemoration site, is in the end always a political decision. Jan-Werner Müller writes in his introduction to Memory and Power in Post-War Europe that the post-communist myths of nationalist salvation, which are in our opinion prominent in Estonia's national identity, lead to the collective forgetting of certain, often darker, parts of the Soviet past. ${ }^{16}$ This process of forgetting the difficult Soviet past was especially salient in the 1990s and 20oos. During the period collective memories were invented geared at uncovering a national identity and history that operated as a form of healing or

\footnotetext{
15 Biran, Poria, and Oren 2011.

16 Müller 2004, 12.
} 
reconciliation with the difficult past. In the 20oos another, second, use of the past became important. Around the time that Estonia acquired its European Union membership (2004), it increasingly positioned itself as a European, nonRussian nation. In this process the difficult Soviet past in which the Estonian nation suffered was increasingly used to distance itself from Russia and explore ties with Europe. In this section we explore this first phase and how it can explain the structural neglect of the site by the nation state. In section five we will explore why the Estonian nation state did not employ this site as a national lieu de mémoire to further the victim narrative.

The first post-Socialist development of dealing with the past in the 1990s is in line with Svetlana Boym's concept of restorative nostalgia. ${ }^{17}$ By 'restorative nostalgia', Boym means a form of nostalgia focused on rebuilding the past. This development is mainly focused on the transition from a Socialist to a 'western' country and the legitimization of the uncovered nationalist identity. The postSocialist context of the Baltic States' restorative nostalgia manifests itself as a longing for the pre-occupation period of the 1920 and earlier. ${ }^{18}$ The Soviet past is not only seen as a rupture, but also as a form of imperialism, where the national identity was hijacked for a certain amount of time by the occupant. Irina Novikova uses the city centre of Tallinn as an example of this restorative heritage discourse: immediately after Estonia regained its independence, Tallinn's old town was considered as proof of this historic continuity due to the Hanseatic look and past of this part of the city, which has a bigger resemblance with north-western European cities than (post-)Soviet cities. ${ }^{19}$ After the fall of the Soviet regime, the city centre was 'decolonized' from obvious signs of the occupation.

However, Lauri Malksöo argues that it is too simplistic to assume that uncovering the national past is merely a technique of political engineering in order to make the transition to the liberal, western discourse. She stresses that this is also a form of dealing with the past, because during the Soviet occupation any form of nationalism was suppressed in Estonia and the institutionalized past was changed to fit the socialist ideal. By uncovering the national past, and documenting memory Estonia got the chance to deal with the occupation by dealing with pasts that were in danger of being forgotten for good. ${ }^{20}$ One of the developments of uncovering the national past in order to deal with it is by unfreezing the 'national' perspectives on World War II past and altering the

\footnotetext{
17 Boym 2001.

18 Novikova 2011, 307.

19 Ibid., 307.

20 Mälksoo 2011, 12.
} 
Soviet understanding of this past to make it fit to the national narrative. ${ }^{21} \mathrm{Un}$ freezing this past was essential in the development of Estonia as a post-Socialist country since it gave the country the chance to deal accordingly with the World War II traumas of the start of the second Russian occupation.

As is becoming clear, not only remembering was an essential part of (re)constructing the national identity, but also the act of forgetting the Socialist past was important. During the 199os the Baltic States shied away from dealing with the Soviet past in order to accelerate the transition to a modern, European nation-state. The problem with leaving the past alone and focusing on the future is that 'the future' cannot replace the past. The past can only be replaced with another past fitting the narrative of the desired future. Most Soviet symbols were removed immediately after the dissolution of the Soviet Union in the 199os, and sites such as Patarei were left to disintegrate throughout most of the 1990s-20oos. Within the national narrative, up to the mid-20oos, the Soviet past remained an untold past.

\section{The Estonian Heritage Society}

The EMS is Estonia's most activist NGO in the field of heritage preservation. Founded on 12 December 1987 during the Soviet period, the organization has been fighting for the preservation of Estonian heritage. Key in the organization is Trivimi Velliste, an important figure in the Estonian liberation movement in the late 1980 os and 1990s. EMS is passionate about the fate of the fort because they believe that it is important that the Soviet (i.e. Russian) atrocities that have been inflicted on the Estonian nation during the occupations will be remembered. Therefore, they believe the best solution is to make a museum and a conference centre out of Patarei. The slogan of EMS is 'heritage protection is the protection of our (Estonian) future'. According to Velliste, Patarei needs to be a symbol of the grim past.

The goal to preserve the past associated with the Patarei Sea Fort in a manner EMS believes to be appropriate is rooted in the fort's use as a source of healing and reconciliation and as a way of harbouring the Estonian national identity. Therefore, for this group, it is important to have a material place associated with that past to commemorate it. Additionally, looking to the slogan of the heritage society itself, it is clear that such a commemoration site is also symbolic for what Estonia is. The 'victim narrative' of the country underscores the fact that the occupations during the recent past were a disruption of the 
national identity rather than a part of what Estonia actually is. The victim narrative therefore connects the Estonia of today with what Estonia was before it was occupied. Additionally, this perspective also openly poses the Russian occupier as the perpetrator. Apart from that, nominating the heritage site for a European list of recognized European heritage underlines the fact that Estonia wants to position itself as a western, European country, rather than as an 'Eastern' country. With this they actively distance themselves from the Russian identity, and therefore it is a strategic move to collaborate with Europa Nostra on this case and ideally receive European attention and funding to restore the building and preserve the desired historical narrative accompanying the site.

EMS might position itself as an NGO divorced from the government that has a long history of opposing the state and promoting the preservation of old buildings. As one of the first NGOs engaged in activism for the Estonian past and an associated identity, EMS is far from an apolitical organization without ties to the national political establishment. The NGO is very much defined by the work of its founder Velliste, who is also a member of the national conservative Pro Patria Union party. He served as minister of foreign affairs and was Estonia's representative to the United Nations. He is currently a member of parliament. Although the party, which has been in the governing coalition for most of the 1990s and 2000s, refrains from using an explicit ethno-nationalist discourse, as a national-conservative party it represents the Estonian national group and its rights and promotes Estonian nationalism.

The discourse which the EMS mobilizes in its activism for the transformation of this derelict building into a site of memory of Soviet oppression correlates with the changing historical culture at the turn of the millennium in which the Soviet past became more important. As mentioned earlier, from the mid-200os onwards, it became popular in Estonia to deal with the traumatic occupation period instead of forgetting or repressing it. This period is also called the 'war on monuments' in the academic discourse of post-Soviet memory in Estonia. ${ }^{22}$ Estonia started to preserve and recontextualize 'Soviet debris' in an effort to draw attention to the authoritarian, anti-democratic nature of the Soviet Union and underline the legitimacy of the Estonian state. This shift in dealing with the Soviet past should be connected to broader socio-political changes outside the borders of Estonia.

First, around the same time (1999) President Vladimir Putin started a campaign to reinvent the Russian identity by building on the Soviet legacy, connecting the Russian nation with the achievements of socialism. Furthermore, the Kremlin also directed its nation-building activities to the so-called near 
abroad, meaning all places that were formerly part of the Soviet Union or the Russian Empire and where there are still large groups of ethnically Russian minorities alive today. This near abroad included Estonia, whose Russian minority became increasingly of interest to the Russian state. Therefore, framing everything Soviet as undemocratic further normalizes the importance of an independent and unified Estonian nation. Second, in 2004 Estonia was accepted into the European Union and was positioned as an exemplary country of representing the 'European identity'. The historical fabric of Tallinn was skilfully used to further the European-ness of Estonia, while the Hanseatic historical centre was used as the backdrop during Tallinn's tenure as European capital of culture. In 2011 Soviet markers were used as places of pain and shame to differentiate Estonia from Russia's Slavic sphere of influence.

For the EMS, the Patarei prison has a similar value to be used as vehicle to further the victim narrative in which everything Soviet (read connected to the Kremlin) is instantiated as unwanted and evil. By vilifying the Soviet-Russian past, an Estonian-European future is promoted in which both the Estonian majority and the Russian minority have a shared sense of citizenship, albeit a type of citizenship built around inherently Estonian markers of identity. However, as Tomas Kavaliauskas argues, there remains an enormous gap between the Russian-speaking Estonians and the Estonian nationalists. At the heart of this ethno-cultural chasm lies a differing perception of the end of World War II. While the Russian-speaking minority sees the end of World War II as the liberation of Estonia, Estonian nationalists regard it as the start of the second occupation of Soviet Russia and therefore as part of the country's traumatic past. ${ }^{23}$

The discourse encoded in Patarei by the EMs correlates with the latter narrative. Patarei embodies Soviet occupation and signifies the repression of the Estonian national group by the Soviet-Russian oppressor. It is questionable, however, if such a narrative where one ethnic group is vilified, can cultivate a shared sense of citizenship. The discursive assembling of Patarei by EMs correlates with how another conservative-nationalist party, the Reform Party, used the removal of Soviet World War II memorials to decolonize the capital from celebratory Soviet heritage. In the end, the heritage activism of the Reform party, which was imbued with strong nationalist conceptions of history, backfired and deepened the chasm between the ethnic groups.

The Bronze Soldier (Bronzovyj Soldat), is a Soviet World War II memorial that used to be located at war graves on the Tõnismãgi hill in the city centre of Tallinn. The statue was erected on 12 June 1945 by Soviet officials as a tribute to 
the soldiers of the Red Army that liberated Tallinn on 22 September 1944, and as a remembrance site for the soldiers that had fallen during the liberation. In 2006 two men attacked the Bronze Soldier and demanded the statue be removed on Victory Day, a Russian holiday on 9 May where the victory over Nazi Germany is celebrated. ${ }^{24}$ The men demanded the removal because the statue does not represent an appropriate symbol for the city centre due to the differing perceptions of the end of World War II. In early 2007, the Reform Party used the removal of the Bronze Soldier as one of their main points in the parliamentary campaign, and this party later won the elections.

Dealing with the statue was officially the task of the Tallinn municipality, but they decided to keep the statue on Tõnismãgi Hill. ${ }^{25}$ The official reason of relocating the statue was because the Reform Party feared radical nationalists would destroy the statue themselves, and by removing it officially they believed they would deescalate the situation. ${ }^{26}$ However, on 26 April the Russian-speaking minority started gathering around the statue to protest against its removal. The police were sent to keep the situation under control; however, due to their aggressive way of handling the situation, the protest escalated and turned into a riot. Approximately fifty people were injured, one young man was killed (part of the Russian-speaking minority), and the city centre was completely vandalized. Due to the empty protesting slogans, it is believed that the protest or riot was perhaps organized by Russia, and not by the Estonian Russian-speaking minority. ${ }^{27}$ On 27 April the statue was relocated to the Cemetery of Estonian Defence Forces in Tallinn (outside the city centre).

Just as removing the Bronze Soldier, the plans to rehabilitate Patarei are an attempt at urban decolonization. However, by instantiating the Soviet-Russian presence in Estonia as a moment of oppression and Russian occupation, the Russian minority, who are official citizens of Estonia and have a long history of presence in the region and were often forcefully relocated to the region, are erased from the 'heritage-scapes'. This ultimately furthers the image of the city centre of Tallinn as mono-ethnic and lacking symbols of belonging for minority groups. Ultimately, through heritage activism, it is the non-governmental organisations linked to centre-conservative parties which undermine rather than promote a sense of shared cultural citizenship.

\footnotetext{
$24 \quad$ Krug 2009, 50.

$25 \quad$ Krug 2009, $5^{2 .}$

$26 \quad$ Novikova 2011, 313.

27 "Tallinn Erupts into deadly Riot," The Baltic Times, April 28, 2007, https://www.baltic times.com/news/articles/17774/.
} 
One of the vehicles used by the EMS to normalize and legitimize their conception of history was their submission of the site to Europa Nostra's ' 7 Most Endangered' programme. According to Europa Nostra, this programme 'identifies the most threatened monuments, sites and landscapes in Europe and mobilises public and private partners at all levels to find a viable future for these heritage gems. ${ }^{28}$ The list of sites is published every two years and is supported by the European Investment Bank (EIBI). As research on the politics of World Heritage listing teaches us, having a heritage site labelled by an international organisation as internationally significant can serve as a powerful tool in negotiations within the nation state. ${ }^{29}$ Furthermore, there are also financial opportunities since there is a possibility to get funding from the EIBI when an NGO applies. EMS aims to develop a public-private partnership project so the fort remains open to the public. In the end, the designation as European endangered heritage was aimed at gaining international attention and externalizeE Ms's heritage discourse. Europa Nostra's decision to label the site as internationally significant and under threat was positioned by the EMS as proof that an external objective European institution supports their claim.

However, Europa Nostra is not an a-political European institution. It is a pan-European NGO collaborating with the EIBI for the ' 7 Most Endangered' list. Europa Nostra is the (international) European equivalent of Italia Nostra, the organization that took action to save Venice from flooding in the $1960 s$. It acts as a representative lobby for cultural heritage in Europe, functioning as a catalyst to save European Heritage in danger and aspires to create a heritage network in Europe. It does not offer financial help to the heritage sites it advises on. The EIBI is the non-profit long-term lending institution of the European Union, established in 1958 under the Treaty of Rome. Although Europa Nostra is an independent NGO, and merely has an advisory and catalysing position, due to its collaboration with the EIBI they have authority in the field of heritage and actively promote a European conception of history. It also seems to represent the 'united in diversity' ideals of the European Union. However, recent analyses of the EU's heritage policy shows that unity trumps diversity and that sites and histories that embody a shared European past are selectively promoted. ${ }^{30}$ The NGO Europa Nostra is not an innocent player in this, and through its diverse programs, such as the ' 7 Most Endangered' sites and the

28 “7 Most Endangered Programme," https://www.europanostra.org/our-work/campaigns/ 7-most-endangered/ (accessed on 10 February 2020).

29 Plets 2015.

30 Lähdesmaki 2014, 405 and Niklasson 2013, 153. 
European Union prize for Cultural Heritage, actively promotes heritage initiatives promoting European unity.

The ' 7 Most Endangered' list is a selection of heritage sites which represent the European identity which are deemed to be endangered and in need of international support in order to save them. 'Endangered' mostly means that the site is neglected and in an advanced state of decay. But it could also mean that there are external factors that could alter the meaning, use or look of the site that would endanger the remembrance of the past connected to it. The list is a selection of a maximum of fourteen sites nominated by local NG Os which are concerned about the fate of the site, of which seven are selected as the most endangered. How exactly Europa Nostra selects these sites is confidential. However, there are two main requirements: it must be of European importance and it must be endangered. Both the website of Europa Nostra as well as statements by our interlocutors indicate that the European dimension is extremely important in the selection of the site. For Patarei specifically we were told that the dark Soviet past was deemed as an important theme in the selection because of the large increase of ex-Soviet countries entering the EU in the last two decades.

Shortly after the decision was made to include Patarei on the ' 7 Most Endangered' list, representatives of Europa Nostra visited the site to gather information for their advisory report on the case. The advisory report mainly corresponds with the opinion of the EMS. There is only one difference: the EMS wants to preserve Patarei from a national perspective where the site will act like a place of commemoration of the Estonian past and the Soviet atrocities, while Europa Nostra underlines the European, international importance of the fort. However, in the end, both actors' heritage discourses correlate and are geared at promoting a narrative othering the Soviet-Russian past and promoting a European-Estonian future.

\section{Heritage Politics and State-Led Gentrification}

As outlined above, the lack of attention for Patarei from the government throughout the 1990s and early 2ooos should be connected to the dominant historical culture in the Baltic States where the governments shied away from dealing with the Soviet past. However, from the mid-2ooos onwards this perspective changed, and the Soviet past became a politically valuable past, promoting a unified Estonian mode of cultural citizenship countering Russian influence. As indicated in the example of the Bronze Soldier and other instances, the Estonian state has followed more conservative parties (which were in the coalition) in co-opting the Soviet past and interconnected victim 
narratives in their nation-building activities. However, it seems odd that Patarei, a site perhaps best embodying the terror and atrocities connected to the two episodes of Soviet 'occupation', was not mobilized as a heritage site in their nation-building portfolio.

One important detail about the site is its location in the Kalamaja district, a trendy harbour district which is gentrifying at a fast pace, making the building and it plot of high economic value for both the national state, municipal government, and powerful construction companies. Before this, the Kalamaja district had long had a bad reputation, and had been inhabited by the working class of Russian descent. However, following some redevelopment projects and reconstruction of historical buildings, such as the Seaplane Harbour, the region became a popular district and started attracting a vast amount of middle to high income people, in many cases replacing the Russian minority. As De Casari and Dimova have recently discussed, ${ }^{31}$ historic buildings often present themselves as tools for policy makers in enabling the gentrification of a neighbourhood. Because of the popularity of buildings of a certain age, regardless the histories connected with it, when renovated they can become drivers for local and socioeconomic development. Especially buildings with an industrial monumental look have over the years become extremely popular for the creation of lofts and upper-class apartments. It is clear that for the Estonian state and the municipal government this economic benefit encoded in the Patarei prison, and the possibility to redevelop this formerly difficult district into a clean and wealthy neighbourhood, outweighs its value for nation-building. However, the EMs believes that neglecting and privatizing a site of such national and historical importance is an inappropriate way of dealing with the past in itself.

The Estonian government sees no possibility in funding such a sizeable restoration and therefore decided to sell the building to a private investor. They appointed RKAS to be in charge of the sale, the state-owned real estate company which is linked to the ministry of social affairs. The municipality of Tallinn has no power over Patarei because it is a government-owned building. For this reason, the city cannot influence the decisions of the government concerning the fort directly. However, the city planning department of the municipality was, according to the head of city planning officer Boris Dubovik and the head of the heritage department of the government Siim Raie, involved in rewriting the zoning plan of the site in favour of private development. In this zoning plan they decided to divide the ground the fort is situated on into four parts, in order to make the sale and restoration easier. 
From an economic point of view, the privatization of Patarei is ideal: once renovated the building will contribute to the further gentrification of the neighbourhood, while a private investor pays for the renovation of the building. Keeping it a public property with a historic-cultural function on the other hand would saddle the already cash-strapped national and municipal governments with high rehabilitation and exploitation costs. By selling the site the government earns money and the restoration will be in the hands of a private investor who will enhance the building, making the Kalamaja district an even more profitable and appealing area. Furthermore, at the same time the government evades the risk of burning their hands by inappropriately dealing with a heritage site representing a contested past, as happened with the Bronze Soldier. This is because once the building is sold, dealing with the past will become the responsibility of the new owner.

In the field of heritage and memory studies we have the tendency to treat the politicization of sites and buildings with a historic value as a zero-sum game primarily structured by nationalist agendas and narratives, ${ }^{32}$ meaning that the engagement of the state with material traces of the past is strongly defined by its potential in authorizing specific conceptions of identity and citizenship. ${ }^{33}$ In the case of Patarei, this would have meant that the site would have been turned into a national site of memory because it can be used as symbolic capital to further a victim narrative in which a European and not Russian future of Estonia is legitimized. However, increased attention within the field of heritage studies for the influence of neoliberal agendas on the management of heritage shows that often exceptions to the nationalist norm are allowed, ${ }^{34}$ especially when the economic gains outweigh the nationalist value. This is not different in Estonia; the difficult past is of importance for the Estonian state in their nation building efforts. However, the economic benefits and possibilities the site offers to gentrify a difficult multicultural neighbourhood seem greater and more rewarding. Clearly, heritage is as much about economics as it is about culture.

Postscriptum Patarei in 2019

In November 2017, over one thousand Estonian citizens signed a petition expressing their concerns about the future of the Patarei fort. ${ }^{35}$ With this number

$32 \quad$ Plets 2018.

33 Smith 2006.

34 Plets 2019.

35 Kalaranna Patarei SA, "Kalaranna Fort - Popularly Known as the Patarei Prison," http:// patarei.tallinn.ee/en/ (accessed on 25 October 2019). 
of signatures, the Estonian parliament is obligated to discuss the case. On the 5 December 2017, the minister of Public Administration Jaak Aab announced in a news article of the newspaper Postimees that the Patarei Sea Fort will be auctioned under the guidance of the ministry. The news about the fort stayed rather quiet for a year until April 2018 when a design competition was launched for a museum of communist crimes. One year later, in May 2019, the Patarei exhibition 'Communism is Prison' was opened and until October 2019 already received 36,000 visitors. ${ }^{36}$

The creation of the exhibition was being coordinated by the Estonian Institute of Historical Memory, and is made in collaboration with the Estonian government, the Estonian Ministry of Justice, the Museum of Occupations of Latvia, the Lithuanian Museum of Genocide Victims, the Foundation for the Study of Communist Dictatorship in East Germany, the Polish Institute of National Remembrance, RKAS, and many others. The exhibition is the first step to creating a 1,500 square meter museum and research centre focused on communist crimes. ${ }^{37}$ In November 2019 the fort was auctioned to the private developer Urmas Sõõruma. Sõõruma is known for the redevelopment of the industrial area of the Rotermann quarter in Tallinn. In an interview with the Estonian public broadcasting station, Eesti Rahvusringhääling, he stated that not the entire complex will be used as a museum or research centre, but that it was part of the deal to keep that aspect in the redevelopment plan. However, one of his visions of the redevelopment is to 'cleanse' the site of its bad aura. ${ }^{38}$ In a certain sense, the stakeholders fighting to save Patarei actually got what they wanted. It is unclear why the government and RKAS changed their opinion.

As for the exhibition itself, the plans surrounding the 1,500 square meters reserved for the research centre are in line with the memory narrative in Estonia from the 2000s, emphasizing that the occupation was a rupture. As described on the website, the museum has the ambition to educate the world about the crimes of communism. During the 2ooos it became popular to deal with the communist occupation as a form of healing and reconciliation. In 1998 the Estonian Institute for Historical Memory was founded specifically to

36 "Patarei Exhibition "Communism is Prison" Received over 36.ooo Vistors," https://patarei prison.org/en/patarei-exhibition-communism-is-prison-received-over-36-ooo-visitors/ (accessed on 25 October 2019).

37 Ibid.

38 Eesti Rahvusringhääling, "Urmas Sõõrumaa Patarei Merekindluse Väidetavat halba aurat ei pegla," https://www.err.ee/1005375/urmas-soorumaa-patarei-merekindluse-vaidetavathalba-aurat-ei-pelga (accessed on 21 November 2019). 
do research on the crimes of communism. In 2003, the semi-private Museum of Occupations was opened and was still very focused on the Estonian victim narrative. In 2007 the Bronze Soldier was removed from the city centre as it was seen as an oppressive symbol. Recently the Estonian Museum of Freedom and Occupations, which is independent from the state, has learned from past mistakes. In their new exhibition they take a more nuanced approach because they acknowledge that anti-Soviet discourses only lead to further polarization. However, the new museum in Patarei does not take such an approach and the narrative about the crimes of communism is back on the scene again. The fact that this narrative survives and is being further explored, despite growing acknowledgements about its negative effects, might have to do with the growing perceived threat of Russian annexation and influence. It is true that there is growing attention of the Russian state for its citizens in the near abroad (including Estonia), as the recent annexation of Crimea and the Donbas region in Ukraine illustrates.

\section{8}

\section{Conclusion}

Immediately after the dissolution of the Soviet Union, the newly-founded Estonian republic mobilized history for creating a unified nation. While preSoviet pasts were being celebrated, it also became popular to erase traces of the Soviet past in the urban sphere and collective memory. The bad state of preservation of the Patarei prison stands as a metonym for the lack of attention for the Soviet past. It became especially important in profiling Estonia as a country that fits the 'western' historical discourse. This was done by placing the emphasis on the medieval, Hanseatic past of Estonia and unfreezing a nationalist, western-European perspective on World War II. This was done in order to make an easier transition to the European, 'western' identity. But it was also a way of reconstructing the Estonian national identity, which has been suppressed since the first Soviet occupation in 1940.

Around the time when Estonia became an EU member, in the 2000s, it became popular to uncover the traumatic Soviet past. This was a form of reconciliation, but also a strategic way of accelerating the transition to the European identity and further distancing itself from the Slavic 'East'. An example of this is the Bronze Soldier of Tallinn, a Russian World War II memorial that was removed from the city centre of Tallinn in 2007. However, due to the great symbolic importance of this statue, this was perceived as a form of marginalization of the Russian-speaking minority, and therefore riots broke out after the removal of the statue. 
In this article, the Patarei Sea fort took centre stage in the exploration of the different approaches of engaging with the difficult Soviet past in Estonia. Clearly, different stakeholders driven by different agendas had competing interests in the fort. The EMS and Europa Nostra share a perspective on what should be done with the Patarei fort. Namely, the fort should be restored and kept as a public space. Both organizations wish for the traumatic Soviet and Nazi past of the fort to be remembered by a museum that will be housed in this fortress after the restoration. The EMs wants to save the fort from its decay in order to make it part of the Estonian national identity, a country that has been the victim of foreign occupations of two severe dictatorial regimes. And Europa Nostra and the EIBI are interested in saving the fort because it is a unique structure in the architectural tradition of the European continent, connected to the dark Soviet past.

The Estonian government, however, distanced itself from the fort and tried to get rid of its responsibility of the heritage site by selling it to a private investor through RKAS. First, the site was largely ignored throughout the 1990s and early 2000 s because during this period there was a nation-wide deliberate forgetting of the Soviet past. During the period when the Soviet past became of interest for nation building, it did not receive any attention. We have argued that this has to do with the fact that the fort is situated in a gentrified area. It is a good investment to sell the fort to a private investor who will restore the fort and further develop the Kalamaja district, generating more profit for the state. The third potential reason could have to do with the lessons learned by the government from the violence following the Bronze Soldier. The Estonian government might well be wary of actively remembering the Soviet occupation. It might be afraid to provoke Russia or marginalize its considerable Russian-speaking minority. However, at the same time, by supporting the gentrification of the Kalamaja district, long inhabited by the Russian-speaking minority, they in fact do marginalize that minority by pushing it further outside the city.

\section{About the Authors}

Onessa Novak, MA. is a cultural historian and is currently employed as Personal Assistant of prof. Rosi Braidotti at Utrecht University. Her main research interests are heritage and memory politics in post-Soviet Europe, feminist legacies, and the representation of the subaltern in a wide array of memory practices. Ranging from heritage sites to archive collections, and from the digital to analogue. She is specifically interested in what role (inter)national 
stakeholders have in the creation of historical narratives connected to these memory practices.

Gertjan Plets is an anthropological archaeologist based at Utrecht University, the Netherlands, and specialized in corporate heritage funding and indigenous cultural heritage politics. Since 2009 he has been working in the Altai Republic tracing the impact of Gazprom's corporate social responsibility programmes on local cultural politics and cultural heritage preservation initiatives. Gertjan was previously based at Stanford University, where he researched the role of cultural heritage in global politics. Plets has published on a variety of topics related to heritage and memory politics in Siberia, the World Heritage politics of the Russian Government, and the Russian funding of heritage preservation in the Middle East as a tool of soft power. His research areas have focused on heritage ethics, cultural landscapes, memory politics, cultural history and resource development.

\section{References}

Belford, Paul. "Patarei Prison, Tallinn: Problematic Built Heritage and Dark Tourism." Institute for Archaeologists Buidings Archaeology Group Newsletter (2013), 49-54. Biran, Avital, Yaniv Poria, and Gila Oren. "Sought Experiences at (Dark) Heritage Sites." Annals of Tourism Research 38 (3) (2011), 820-841.

Boym, Svetlana. The Future of Nostalgia (New York: Basic Books, 2001).

Brüggemann, Karsten, and Andres Kasekamp. "The Politics of History and the "War of Monuments" in Estonia." Nationalitites Papers 36 (3) (2008), 425-448.

de Cesari, Chiara, and Rozita Dimova. "Heritage, Gentrification, Participation: Remaking Urban Landscapes in the Name of Culture and Historic Preservation." International Journal of Heritage Studies 25 (9) (2019), 863-869.

Erll, Astrid. Memory in Culture (London: Palgrave Macmillan, 2011).

Garton Ash, Timothy. "Trials, Purges and History Lessons: Teaching a Difficult Past in Post-Communist Europe." In Memory and Power in Post-War Europe, ed. Jan-Werner Müller (Cambridge: Cambridge University Press, 2004), 265-282.

Kavaliauskas, Tomas. "Different Meanings of May gth, Victory Day over Nazi Germany for Russia and the Baltic States." In Interdisciplinary Studies on Central and Eastern Europe: 20 Years after the Collapse of Communisms: Expectations, Achievements and Dissolutions after 1989, eds. Nicolas Hayoz, Leszek Jesien and Daniela Koleva (Bern: Peter Lang 2011), 319-338.

Kõresaar, Ene, and Kristi Jõesalu. "Estonian Memory Culture Since the Post-Communist Turn: Conceptualizing Change Through the Lens of Generation." In Generations in 
Estonia: Contemporary Perspectives on Turbulent Times, eds. Raili Nugin, Anu Kannike and Maaris Raudsepp (Tartu: University of Tartu Press, 2016), 128-158.

Krug, Andres. “The Bronze Soldier Monument and its Public." In After-War, ed. Kristina Norman (Tallinn: Center for Contemporary Arts, Estonia, 2009), 50.

Lähdesmaki, Tuuli. "The EUs Explicit and Implicit Heritage Politics." European Societies 16 (3) (2014), 401-421.

Mälksoo, Maria. "Introduction." In Historical Memory versus Communist Identity, ed. Meelis Saueauk (Tartu: University of Tartu Press, 2011), 9-18.

Müller, Jan-Werner. "Introduction: the Power of Memory, the Memory of Power and the Power over Memory." In Memory and Power in Post-War Europe, ed. Jan-Werner Müller (Cambridge: Cambridge University Press, 2004), 1-35.

Niklasson, Elisabeth. "And We Would Like to Thank the Role of Funding in Archaeology." In Making Cultural History. New Perspectives on Western Heritage, ed. Anna Källén (Lund: Nordic Academic Press, 2013), 151-161.

Novikova, Irina. "Baltic Lieux de Mémoire of the 1990s to Early 200os: Nostalgia, Trauma, Change." In Interdisciplinary Studies on Central and Eastern Europe, eds. Nicolas Hayoz, Leszek Jesien and Daniela Koleva (Tartu: Peter Lang, 2011), 295-310.

Plets, Gertjan. "Ethno-Nationalism, Asymmetric Federalism and Soviet Perceptions of the Past: (World) Heritage Activism in the Russian Federation." Journal of Social Archaeology 15 (1) (2015), 67-93.

Plets, Gertjan. "Heritage Statecraft: Transcending Methodological Nationalism in the Russian Federation." In The Palgrave Handbook of State-Sponsored History after 1945, eds. Berber Bevernage and Nico Wouters (London: Palgrave Macmillan, 2018) 495-509.

Plets, Gertjan. "Exceptions to Authoritarianism? Variegated Sovereignty and EthnoNationalism in a Siberian Resource Frontier." Post-Soviet Affairs 35 (4) (2019), 308-322.

Smith, Laurajane. Uses of Heritage (London: Routledge, 2006).

Tammaru, Tiit, Maarten van Ham, Kadri Leetmaa, Anneli Kährik, and Kristiina Kamenik. "The Ethnic Dimensions of Suburbanisation in Estonia." Journal of Ethnic and Migration Studies 39 (5) (2013), 845-862. 